\title{
Infiltration-Friendly Land Uses for Climate Resilience on Volcanic Slopes in the Rejoso Watershed, East Java, Indonesia
}

\author{
Didik Suprayogo ${ }^{1}$, Widianto ${ }^{1}$, Kurniatun Hairiah ${ }^{1}$, Nabilla Meilasari ${ }^{1}$, Abdul Lathief Rabbani ${ }^{1}$, Rizky \\ Maulana Ishaq ${ }^{1}$, Meine van Noordwijk ${ }^{1,2,3}$
}

${ }^{1}$ Soil Science Department, Faculty of Agriculture, Brawijaya University, Jl. Veteran no 1, Malang 65145, Indonesia

${ }^{2}$ World Agroforestry Centre, ICRAF, Indonesia Office, Bogor, Indonesia

${ }^{3}$ Plant Production Systems, Wageningen University, Wageningen, The Netherland

10 Correspondence to: Didik Suprayogo (Suprayogo@ub.ac.id and Suprayogo09@yahoo.com)

Abstract. Forest conversion to agriculture or agroforestry may increase risks of loss of hydrologic functions in an era of
climate change. Infiltration during high-intensity rainfall is important for avoiding erosion and feeding aquifers but depends
on land use practices that maintain soil macroporosity. In the forest-to-open-field-agriculture continuum it is not clear where
thresholds to functionality ('degradation') are crossed. Our assessment of 'infiltration-friendly' land uses in the Rejoso

15 watershed on the slopes of the Bromo volcano in East Java (Indonesia) focused on two zones, upstream (above $800 \mathrm{~m}$ a.s.l.) and midstream (400-800 m a.s.l.) of the Rejoso river and feeding aquifers that support lowland rice areas as well as drinking water supplies to nearby cities. Upstream land uses included old and young pine plantations (production forest) and highland vegetable crops with variation of tree canopy cover. Midstream land uses included production forest, multistrata coffee-based agroforestry, clove-based agroforestry, and several mixed agroforestry types with variation of tree canopy cover. We quantified infiltration and erosion in three replications per land use category over a three-month period (one-third of mean annual rainfall), with $6-13 \%$ of rainfall with intensities (51-100 $\mathrm{mm} \mathrm{day}^{-1}$ ). We related infiltration rates to plot-level characteristics across the land use systems and found statistically significant relations with tree canopy cover (likely based on combined effects of interception, preceding water use and effects on soil), understory cover, amount of litter, and soil surface roughness. Results for the upstream watershed showed that a tree canopy cover $>55 \%$ is associated with adequate infiltration and acceptable soil erosion levels. For vegetable cultivation in steep (45-65\%) to very steep (> 65\%) lands with a tree canopy cover below 55\%, surface runoff was between $24 \%$ and $46 \%$ of rainfall, with high rates of soil erosion. Midstream, a tree canopy cover of $>80 \%$ was associated with 'infiltration-friendly' land use, given the higher rainfall total (and rainfall intensity) in this zone. For a tree canopy cover in the range $20-80 \%$, erosion rates were relatively low, but surface runoff increased to 36 to $62 \%$ of rainfall. Differences in soil type influenced the thresholds, as the areas' Inceptisols have lower intrinsic porosity than Andisols. A high soil surface roughness and litter thickness assist in reducing surface runoff and soil erosion. Where more open forms of agroforestry, with tree canopy cover less than $80 \%$ are becoming more common this will affect water resources in the downstream area and increase vulnerability to climate change. 


\section{Introduction}

Water access for all, Sustainable Development Goal 6 of the Agenda 2030 agreed by the United Nations (UN-Water, 2018), not only refers to drinking-water and sanitation. It requires the protection of infiltration-friendly land uses in upland watersheds as a source of clean water (Ostovar, 2019). Sufficient groundwater recharge is important to sustainable management of groundwater resources to maintain streamflow throughout the year (Ali et al., 2016, Jacobs et al., 2018). While much of the public discourse is in terms of forest versus agriculture, thresholds for specific soil and climate regimes are needed within the intermediate agroforestry spectrum of land uses (van Noordwijk et al. 2014). Thresholds to critical hydrological functions are likely dependent on local context but need to be understood to guide natural resource management in the challenging tradeoffs between local and external priorities (van Noordwijk et al. 2019). Wiersum (1984) documented that a high pine tree canopy, without understory and permanent litter layer, can lead to high erosion rates due to high-impact drips from the needles.

Agroforestry systems with high canopy density can, if a permanent litter layer is present, maintain high infiltration rates and can positively impact on hydrologic functions through: (1) a green canopy cover at tree and understorey level, (2)

45 land surface roughness, (3) litter at the soil surface, and (4) water uptake by trees and other vegetation (Hairiah et al., 2004, Suprayogo et al., 2017). Five aspects that hydrologically differentiate natural forest from open-field agriculture, with intermediate functionality for managed forest, plantations, agroforestry and trees outside forest (Creed and van Noordwijk, 2018; Jones et al. 2020) are: 1) the leaf area index (LAI) that allows photosynthesis when stomata are open and transpiring, and that along with leaf morphology and rainfall intensity, determines canopy interception and subsequent evaporation, 2) the surface litter that prevents crusting and supports infiltration (Liu et al., 2019), while reducing soil evaporation and reduces entrainment of soil particles if overland flow still occurs, 3) the soil macroporosity that governs infiltration and allows for aeration of deeper soil layers between rainfall events while recovering at decadal time scale after reforestation (Zhang et al. 2018 , 2019), 4) the root systems that govern water extraction from deeper soil layers, in conjunction with the phenology of the aboveground canopy, 5) possible influences on rainfall events (Ellison et al. 2017, 2019). Each of these five aspects has its own dynamic (time constants) and dependency on the type of trees and their management, challenging definition of hydrologically adequate land use choices. Rather than prescribing, independent of soil types and slope, the type and quantity of tree cover that is needed as tends to happen in forest zoning, it may help if limits to infiltration-friendly land use (focussed on the third function) can be operationalized in local context. In terms of watershed hydrology, infiltration-friendly land uses can be interpreted as any land use that allows high rates of water infiltration so that surface runoff is a small (to be defined in local context) fraction of rainfall and the watershed functions of flow buffering and erosion control are secured (to specified standards). In watersheds that provide a perfect buffering river flow might theoretically be constant every day, but in practice a 'flow persistence' metric of about 0.85 is hard to surpass (van Noordwijk et al., 2017). Flow buffering is essential for Climate Resilience (Aduah et al., 2017; Shannon et al., 2019) and high flow persistence metrics are desirable, as they directly relate to peak flow transmission (van Noordwijk et al., 2017). . 
65 On densely populated Java volcanic slopes are home to large numbers of farmers, while also serving as sources of water for lowland agriculture and the rapidly growing cities. The shrinking area of state-managed forests is no longer able to secure the required watershed functions, but at least part of the agroforestry managed by farmers can meet the required hydrological functions (Sajikumar and Remya 2015). In the Rejoso Watershed (Pasuruan, East Java, Indonesia), numerous stakeholders depend on the watershed functions of densely populated mountain slopes to meet their water demand. These include local communities, farmers using water irrigation, the Regional Water Company, and bottled-water industries. A major infrastructure is planned to bring water to Surabaya and surrounding urban centres. However, the quantity and quality of the water at the source of the pipe have been decreasing over the past 10 years, putting the infrastructure investment at risk. Decreasing water resources are likely due to land use changes in the recharging area of Rejoso watershed on the northern slopes of the Bromo-Semeru volcanic mountain range, and/or decreased pressure on Artesian wells in the lands due to increased extraction for paddy rice-fields. Among the hydrologic functions, infiltration is critical, as water travels through the subsoil to artesian wells at the foot of the volcano, in addition to surface rivers.

This research was thus designed to assess which land uses can maintain infiltration rates under local peak rainfall intensity and restrict soil erosion to acceptable levels. Specific questions were:

1) Which existing land uses limit infiltration below the required rates at peak rainfall events?

2) Which factors that are directly observable such as tree cover, litter layer thickness or surface roughness can be used to define thresholds for 'infiltration-friendly land use'?

3) Do answers to questions 1 and 2 need to be differentiated between the upper and middle watershed, with current vegetable production and agroforestry as dominant land uses, respectively?

\section{Material and methods}

\subsection{Study area}

The Rejoso watershed, is located in the foothills of Mount Bromo, covering 16 sub-districts in Pasuran District, East Java Province, Indonesia. The Rejoso watershed covers an area of 63,359 hectares with a watershed length of about $22 \mathrm{~km}$. This study was conducted in two locations, namely in the upstream (above $800 \mathrm{~m}$ a.s.1.) and midstream (400-800 m a.s.1.) sections, with the dominant vegetation (land cover) selected for each location (Figure 1). In each location four dominant land use systems were assessed (Table 1), spatially replicated in three separate measurement plots.

$\Rightarrow$ Fig. 1

$\Rightarrow$ Table 1 


\subsection{Rainfall}

Rain gauges (ombrometers) were installed in four observation locations (with adjacent erosion plots) upstream and four observation locations midstream of the Rejoso watershed. Each plot, the rainfall was measured with 5 replications. The ombrometers consisted of a funnel and bottle with a volume of $1.5 \mathrm{dm}^{3}$ placed $120 \mathrm{~cm}$ above the soil surface and below the tree canopy with bamboo as a support. Rainfall was observed every day during three months of the rainy season, from March to May 2017.

\subsection{Infiltration and soil erosion measurement}

Infiltration was quantified in each land cover type via its complement, surface runoff, and expressed in the Runoff / Rainfall ratio. As rainfall for quantified infiltration was measured below the tree canopy, the amounts were net of canopy retention. Surface runoff was measured in $6 \mathrm{~m} \times 2 \mathrm{~m}$ plots protected from surface run-on, with two drums at the lower end to collect surface runoff and sediment concentrations for soil erosion measurement (Figure 2). In each plot, the water flow out through 13 holes of PVC pipes on drum-I was calibrated to be equal volume of water in each hole before runoff measurement. Runoff samples were collected on every day at which rain occurred during the measurement period by measuring the water depth in each drum. The amount of runoff in each rain even was calculated using eq. (1) and eq. (2):

$$
\begin{aligned}
& R_{t}=V_{d-I}+\left(13 * V_{d-I I}\right) \\
& V_{d}=10 *\left(\frac{\pi r^{2} D}{A}\right)
\end{aligned}
$$

Where $R_{t}$ is total runoff $(\mathrm{mm})$; $V_{d}$ is the water volume in drum I and II $(\mathrm{mm}), r$ is the radius of drum $(\mathrm{cm})$, D is the water depth in each drum $(\mathrm{cm})$, and $\mathrm{A}$ is the areas of plot $\left(\mathrm{cm}^{2}\right)$.

The soil erosion in each rain even was determined by collecting $1000 \mathrm{~cm}^{3}$ of runoff-sediment in each drum. The sample was filtered with "newsprint" and dried in the oven with temperature $105^{\circ} \mathrm{C}$ to get the weight of sediment (S). The soil erosion in each rain even was calculated using eq. (3):

$$
E=\left(\left(\left(\pi * r_{d-I}^{2} * D_{d-I}\right) * S\right)+\left(13 *\left(\left(\pi * r_{d-I}^{2} * D_{d-I}\right)\right) * 10^{-6}\right) * S\right) *\left(\frac{10^{8}}{A}\right)
$$

115 Where $\mathrm{E}$ is soil erosion (ton $\left.\mathrm{ha}^{-1}\right)$; $\mathrm{S}$ is sediment $(\mathrm{g})$.

$\Rightarrow$ Fig. 2 
https://doi.org/10.5194/hess-2020-2

Preprint. Discussion started: 20 February 2020

(C) Author(s) 2020. CC BY 4.0 License.

(c) (i)
Hydrology and

Earth System

Sciences

Discussions

\subsection{Determination of soil properties}

Three bulk mineral soil samples were collected from the upper $20 \mathrm{~cm}$ below the litter layer at each site (A horizon). Particle size distribution (particles $<2 \mathrm{~mm}$ ) was determined with the Bouyoucos densimeter method (Gee and $\mathrm{Bauder}$ 1986) after $\mathrm{H}_{2} \mathrm{O}_{2}$ pre-treatment and after samples had been dispersed in a 5\% sodium hexametaphosphate 5\% dispersing solution. Bulk density (oven dry weight per unit volume) was measured for a block-sized sample $\left(20 \mathrm{~cm}\right.$ x $\left.20 \mathrm{~cm} \times 10 \mathrm{~cm}=4000 \mathrm{~cm}^{3}\right) \mathrm{collected} \mathrm{at}$ field-moisture conditions (modified from Blake and Hartge, 1986). Total soil porosity $(\varnothing)$, the percentage of the total soil volume that is not filled by solid (soil) particles (Nimmo, 2004), was calculated from bulk density data and particle density using Eq. (4):

$$
\emptyset=\left(1-\frac{\rho_{b}}{\rho_{p}}\right) \times 100 \%
$$

where $\emptyset$ is porosity $(\%) ; \rho_{\mathrm{b}}$ is bulk density $\left(\mathrm{g} \mathrm{cm}^{-3}\right)$, and $\rho_{\mathrm{p}}$ is particle density $\left(\mathrm{g} \mathrm{cm}^{-3}\right)$.

Soil organic carbon (SOC) was determined by dichromate oxidation (Walkley and Black, 1934).

\section{$130 \quad 2.5$ Other plot characteristics}

\subsubsection{Canopy cover}

The percentage of canopy cover in each plot was calculated using the grid method, that records the shadow of sunshine at ground level using plastic or paper (Arumsari, 2003 in Astutik, et al., 2015). The canopy projection when the sun was overhead was drawn to scale on millimetre paper in each of four quadrants of the $20 \mathrm{~m} \mathrm{x} 20 \mathrm{~m}$ plots, after which the areas shaded were cut out and weighed separately. Canopy cover was calculated according to eq. (5):

$$
\% \mathrm{CV}=\frac{W \text { Canopy }}{W \text { Total }} X 100
$$

Where: \%CV is the percentage of tree canopy cover, W_Canopy is the paper weight representing canopy cover and W_Total the paper weight representing the total area of observation, respectively. 


\subsubsection{Understorey and litter}

140 Understorey vegetation and litter were measured according to the rapid carbon stock appraisal protocol (Hairiah et al., 2005), using $50 \mathrm{~cm}$ x $50 \mathrm{~cm}$ samples for fresh weight, with subsamples dried for dry weight determination.

\subsubsection{Land surface roughness}

Surface roughness was measured in each plot as the standard deviation of elevation measured every $30 \mathrm{~cm}$ along a thread (thin rope) installed $30 \mathrm{~cm}$ from the surface vertically, horizontally and diagonally over the erosion plot (Hoechstetter et al., 2008).

\section{2.6. Data analysis}

GenStat $15^{\text {th }}$ edition was used for the statistical analysis of the results. The Fisher's LSD test, which establishes differences between groups defined for independent samples, was used for hypothesis testing, given that the data met the requirements for normality and homogeneity of variances. A probability level of 0.05 was set for rejecting null-hypotheses of no difference in tests of statistical significance. Linear regression relationships between the surface runoff / rainfall ratio or soil erosion and the

150 amount of rainfall, tree canopy cover, understory, litter, and land surface roughness were determined using SigmaPlot version10.0.

\section{Results}

\subsection{Rainfall}

Within the measurement period 31 rainy days were recorded (Figure 3). Rainfall variation between upstream and midstream observation plots was relatively high with an average of $520 \mathrm{~mm}$ (range $476-556 \mathrm{~mm}$ ), and an average $666 \mathrm{~mm}$ (range 541 $840 \mathrm{~mm}$ ), respectively. In the upstream and midstream areas $71 \%$ and $57 \%$ of the rainy days had $<20 \mathrm{~mm}^{-1}$ day $^{-1}$ ('light rain'), $24 \%$ and $31 \%$ had 'moderate' rainfall (21-50 $\left.\mathrm{mm} \mathrm{day}^{-1}\right)$ and $6 \%$ and 13\% 'heavy' rain (51-100 $\left.\mathrm{mm} \mathrm{day}^{-1}\right)$, respectively; none had 'very heavy rain' $\left(>100 \mathrm{~mm} \mathrm{day}^{-1}\right)$. Such rain conditions indicate that the rain-erosivity in midstream is higher than that upstream.

$160 \Rightarrow$ Fig. 3

\subsection{Soil properties}

The upstream area had lower bulk density and higher soil porosity, with lower clay content than the midstream area (Table 2). The $\mathrm{C}_{\text {org }}$ concentrations varied from 0.65 to $2.12 \%$.

$\Rightarrow$ Table 2 


\section{3.3. Land characteristics related to runoff and soil erosion}

Production forests in the upstream area had a lower tree canopy cover than those midstream but higher than those in agroforestry systems (Table 3). Agroforestry in the upstream area had a very low tree canopy cover because trees were planted only along field edges. Midstream agroforestry gardens ranged from high (75\%) to low (26\%) canopy cover. Understorey vegetation was more prominent upstream than midstream. Litter layer necromass and land surface roughness were generally aligned with tree canopy cover.

$\Rightarrow$ Table 3

\subsection{Runoff and soil erosion}

Decreasing tree canopy cover in agroforestry systems significantly increased the surface runoff / rainfall ratio (Table 4).

$\Rightarrow$ Table 4

175 Upstream production forests, with relatively coarse-textured soil (Table 2) had, despite steeper slopes (38-56\%), a lower surface runoff / rainfall ratio than those in the midstream area with finer-textured soils and low land slope (3 -8\%). In the upstream area, with decreasing tree canopy cover, the surface runoff / rainfall ratio increased 16-fold times compared to production forest (Figure 4.a). In the midstream area, agroforestry systems with a tree canopy cover $>80 \%$, were still able to support low surface runoff (Figure 4.b). With a tree canopy cover of $<80 \%$, surface runoff increased rapidly on days with moderate rainfall (20-50 $\left.\mathrm{mm} \mathrm{day}^{-1}\right)$ (Figure 4.b.).

$\Rightarrow$ Fig. 4

In production forests with closed tree canopy cover, soil erosion rates were low (Table 4 and Figure 5 a.1, a.2 and b.1). These production forests still had a protective understorey vegetation, that contributed to litter necromass and surface roughness (Table 3), controlling splash erosion. Upstream, with reduction of tree cover canopy soil erosion increased dramatically from

18520 to 110 times the rates measured in forested plots (Table 4).

$\Rightarrow$ Fig. 5

Erosion rates in all plots increased with rainfall intensity (Figure 5.a.3. and Figure 5.a.4). Midstream agroforestry systems had erosion rates range from 2.8 to $10.3 \mathrm{t} \mathrm{ha}^{-1}$ in the measurement period (Table 4). As annual rainfall is approximately three times what was recorded in the measurement period, with similar rainfall intensities, these erosion rate are to be multiplied by a

190 factor of 3, leading to $9-31 \mathrm{t} \mathrm{ha}^{-1}$ year $^{-1}$. Even on volcanic soils, with frequent ash inputs, such erosion levels may be challenging sustainability. 


\subsection{Thresholds for infiltration-friendly land use}

Increasing tree canopy cover, while maintaining understorey vegetation and litter necromass, is a strong indicator of watershed health as the main driver of low surface runoff (or high soil infiltration) and low soil erosion in production and agroforestry forest systems in the Rejoso watershed (Figure 6.a.1, 6.b.1. and Figure 7.a.1, 7.b.1).

$\Rightarrow$ Fig. 6

Understorey vegetation reduces splash impacts on the soil and supports infiltration, as does the litter necromass present. (Figures 6.a.3, 6.b.3. and Figure 7.a.3, 7.b.3). Land surface roughness, in contrast to litter necromass, had no consistent relationship with runoff or erosion (Figure 6.a.4. and Figure 7.a.4).

\section{Discussion}

A number of land cover types had infiltration rates below the required rates at peak rainfall events. Among the four factors tested, tree cover and litter layer necromass could be used to define zone-specific thresholds for infiltration-friendly land use, but understory vegetation and surface roughness did not. Although slopes in the upper watershed are much steeper than midstream, the coarser texture and likely higher aggregate stability means that thresholds for canopy cover and litter necromass can be lower.

Many authors have emphasized that the key to hydrologic functions is in the soil rather than the aboveground parts of the forest (Peña-Arancibia et al. 2019). Still, we found strong and direct relations with canopy cover. Positive effects of canopy cover on infiltration were related to raindrop interception in earlier studies (Carlesso et al. 2011; de Almeida et al. 2018). Interception

210 will (a) reduce the destructive power of rainwater splash on the ground surface (as long as the effects Wiersum (1974) described are avoided, (b) allow more time for infiltration as water reaches the surface more slowly, (c) keep a thin water film on the leaves that will (d) cool the surrounding air when it subsequently evaporates. It will reduce the amount of water reaching the soil surface, but by increasing air humidity also decrease transpiration demand when stomata are open. In a study in North China, Li et al. (2014) showed that presence of litter of Quercus variabilis, representing broadleaf litter, and Pinus

215 tabulaeformis, representing needle leaf litter, can reduce surface runoff rates by $29.5 \%$ and $31.3 \%$ respectively. The overall effect of fast plus slowly decomposing surface litter means protection of the soil surface from splash erosion, surface roughness that reduces sediment entrainment, an energy source for soil biota and a conducive microclimate (Hairiah et al. 2006, Derpsch et al., 2014).

Both the production forest and agroforestry systems maintained a relatively high land surface roughness. Without a high canopy cover this roughness was not able to control surface runoff and erosion in the upstream area, but midstream there were significant correlations. The role of surface roughness as sediment filter may depend on frequent regeneration to counter 
homogenisation (Rodenburg et al. 2003). The soils' macroporosity, needed for effective infiltration, is the result of a continuous process of compaction and filling in of macropores with fine soil particles, and creation of biogenic channels (formed by old tree roots, earthworms and other soil engineers) or abiotic processes (cracks). As no heavy machinery is used in any of these land use systems, compaction is restricted to human feet, and motorbikes in specific tracks. The formation of old tree root channels can cause long time-lags between land cover change and soil macroporosity (van Noordwijk et al. 2011), obscuring relations between current tree cover and hydrologic functions. Zwartendijk et al. (2017) showed that 'fallows' were intermediate between forests and grasslands in terms of infiltration in Madagascar. Recovery of infiltration after reforestation of grasslands in the Philippines was found to be a matter of decades rather than years (Zhang et al. 2019).

From a land use policy perspective our results suggest that maintaining high $(\sim 80 \%)$ canopy cover in the mid-slope farmercontrolled landscape that does not match the slope criteria for designation as watershed protection forest, is important. In Indonesia, protection is forest areas that have the primary function as protection of life support systems to regulate water management, prevent flooding, control soil erosion, prevent sea water intrusion, and maintain soil fertility (Government of Indonesia, 1999). With the higher rainfall intensities here and more erosive soils, risks for degradation from a downstream perspective seem to be as important here as they are in the more visually-at-risk upper watershed zone. Combining our plotlevel results with efforts for hydrologic modelling for the Rejoso catchment as a whole (Tanika et al. 2018) can guide further advice to a local watershed forum on the measures and incentives needed to restore and protect the watershed as a whole. The Indonesian legal requirement of $30 \%$ forest cover across all its local government entities (Government of Indonesia, 2007) is a coarse translation of hydrologic relations at risk. It clearly matters what the land cover in the 'non-forest' parts of the landscape is and how vegetation interacts with soils and geomorphology in shaping rivers and groundwater flows (Zhipeng et al. 2018; Zhao et al. 2019). Our findings for the Rejoso watershed show that within the agroforestry spectrum, hydrologic thresholds of infiltration-friendliness exist between the systems that are mostly 'agro' and those that are mostly 'forest'.

\section{Conclusions}

Our results demonstrated that vegetation-based thresholds for adequacy of infiltration, given the existing rainfall intensities,

245 differed between the upper and middle watershed. Despite steep slopes and low tree cover, the upper watershed with its coarse soil texture and strong aggregation typical of Andosols, land management practices that combine vegetable crops with a tree canopy cover of around $55 \%$ can maintain infiltration and reduce erosion to acceptable levels. In the midstream part of the catchment, despite gentle slopes, infiltration-friendly land use on the fine-textured Inceptisols required a canopy cover of $80 \%$. Beyond tree canopy cover, litter layer necromass was found to be a good and easily observed indicator of infiltration rates, 
Author contributions. DS, W, KH and MvN was designed the study. NM was collected data in midstream, ALR was collected data in upstream, RMI was coordinated to collect the data in the field, academically supervised by DS, W and KH. Didik Suprayogo, DS, W, KH and MvN shaped the manuscript, which was approved by all co-authors.

Competing interests. The authors declare that they have no conflict of interest.

\section{Acknowledgements}

Authors thank to the community of Rejoso watershed and the "Rejoso Kita" Forum. They also thank the Department of Soil Science, Faculty of Agriculture, University of Brawijaya and the Research Group of Tropical Agroforestry for support of the research. Finally, the authors would like to thank the Social Investment Indonesia (SII) organisation for connecting the local stakeholders during field work.

260 Financial support. This research has been supported by the Danone Ecosystem Fund via the World Agroforestry Centre, ICRAF, Indonesia Office. This research is also partially funded by the Indonesian Ministry of Research, Technology and Higher Education under WCU Program managed by Institute of Research and Community Services Universitas Brawijaya and Institut Teknologi Bandung.

\section{References}

Aduah M.S., Jewitt G.P.W., Toucher M.L.W. Scenario-based impacts of land use and climate changes on the hydrology of a lowland rainforest catchment in Ghana, West Africa. Hydrol. Earth Syst. Sci. Discuss., https://doi.org/10.5194/hess2017-591. 2017

Ali M., Hadi S., and Sulistyantara B. Study on land cover change of Ciliwung downstream watershed with spatial dynamic approach. CITIES 2015 International Conference, Intelligent Planning Towards Smart Cities, CITIES 2015, 3-4 November 2015, Surabaya, Indonesia. Procedia - Social and Behavioral Sciences 227: 52 - 59. 2016

Alvarenga, L.A., de Mello C.R., Colombo A., Cuartas L.A., Bowling L.C. Assessment of land cover change on the hydrology of a Brazilian head-water watershed using the Distributed Hydrology-Soil-Vegetation Model. Catena 143: 7-17. http://dx.doi.org/10.1016/j.catena.2016.04.001 2016.

Anache J.A.A., Wendland E., Rosalem L.M.P., Youlton C., Oliveira P.T.S. Hydrological trade-offs due to different land covers and land uses in the Brazilian Cerrado. Hydrol. Earth Syst. Sci., 23, 1263-1279. https://doi.org/10.5194/hess-23-1263. 2019 
Boongaling C. G.K., Faustino-Eslava D.V., Lansigan F.P., Modeling land use change impacts on hydrology and the use of landscape metrics as tools for watershed management: The case of an ungauged catchment in the Philippines. Land Use Policy, Vol. 72:116-128; https://doi.org/10.1016/j.landusepol.2017.12.042 2018.

Blake, G.R., Hartge, K.H. Bulk density. In: Klute, A.K. (Ed.), Methods of soil analysis. Part I: Physical and mineralogical methods. American Society of Agronomy - Soil Science Society of America, Madison, pp. 363-375. 1986

Carlesso, R., Spohr, R.B., Eltz, F.L.F., Flores, C.H. Runoff estimation in southern Brazil based on Smith's modified model and the Curve Number method. Agric. Water Manag. 98, 1020-1026.2011.

Choto, M. and Fetene A. Impacts of land use/land cover change on stream flow and sediment yield of Gojeb watershed, OmoGibe basin, Ethiopia. Remote Sensing Applications: Society and Environment 14: 84-99. https://doi.org/10.1016/j.rsase.2019.01.003. 2019.

Creed IF, van Noordwijk M. Forest and water on a changing planet: Vulnerability, adaptation and governance opportunities.

A Global Assessment Report. World Series Volume 38. Vienna. Austria: IUFRO. 2018

Derpsch, R., Franzluebbers, A.J., Duiker, S.W., Reicosky, D.C., Koeller, K., Friedrich, T., Sturny, W.G., Sá, J.C.M., Weiss,

K. Why do we need to standardize no-tillage research? Soil Tillage Res. 137, 16-22. 2014.

de Almeida W.S., Elói Panachuki E., de Oliveira P.T.S., da Silva Menezes R., Sobrinho T.A. , de Carvalho, D.F. Effect of soil tillage and vegetal cover on soil water infiltration. Soil \& Tillage Research 175: 130-138 http://dx.doi.org/10.1016/j.still.2017.07.009.2018.

Ellison, D., Morris, C.E., Locatelli, B., Sheil, D., Cohen, J., Murdiyarso, D., Gutierrez, V., van Noordwijk, M., Creed, I.F., Pokorny, J. Trees, forests and water: cool insights for a hot world. Global Environmental Change 43:51-61. 2017

Ellison, D., Wang-Erlandsson, L., van der Ent, R.J. and van Noordwijk, M. Upwind forests: managing moisture recycling for nature-based resilience. Unasylva, 251, 13-26. 2019

Gee, G.W. and J.W. Bauder. Particle Size Analysis. In: Methods of Soil Analysis, Part A. Klute (ed.). 2 Ed., Vol. 9 nd . Am. Soc. Agron., Madison, WI, pp: 383-411. 1986

300 Government of Indonesia. Law (Undang-undang) Number 41 Year 1999 about Forestry. 1999.

Government of Indonesia. Law (Undang-undang) Number 26 Year 2007 about Spatial Planing. 2007

Hairiah K, Sulistyani H, Suprayogo D, Widianto, Purnomosidhi P, Widodo R H, and Van Noordwijk M. Litter layer residence time in forest and coffee agroforestry systems in Sumberjaya, West Lampung. Forest Ecology and Management 224: 45 57. 2006. 
Jacobs S.R, Timbe E., Weeser B., Rufino M.C., Butterbach-Bahl K., and Breuer L. Assessment of hydrological pathways in East African montane catchments under different land use. Hydrol. Earth Syst. Sci., 22, 4981-5000, https://doi.org/10.5194/hess-22-4981-2018

Jones JA, Wei X, Archer E, Bishop K, Blanco JA, Ellison D, Gush M, McNulty SG, van Noordwijk M, Creed IF. ForestWater Interactions Under Global Change. pp. 589-624 in: D.F.Levia et al. (Eds) Forest-Water Interactions. Ecological Studies 240. Springer Nature, Switzerland 2020. https://doi.org/10.1007/978-3-030-26086-6_24

Kellner, E. and Hubbart J.A. A method for advancing understanding of streamflow and geomorphological characteristics in mixed-land-use watersheds. Science of the Total Environment 657: 634-643. https://doi.org/10.1016/j.scitotenv.2018.12.070. 2019.

Li X, Niu J, Xie B. The Effect of Leaf Litter Cover on Surface Runoff and Soil Erosion in Northern China. PLoS ONE 9(9): e107789. doi:10.1371/journal.pone.0107789. 2014

LiuY., Zeng Cui, Z., Huang Z., Hai-Tao Miao, H.T. and Wu, G.L. The influence of litter crusts on soil properties and hydrological processes in a sandy ecosystem. Hydrol. Earth Syst. Sci., 23, 2481-2490. https://doi.org/10.5194/hess-232481-2019. 2019.

Ostovar, A.L. Investing upstream: Watershed protection in Piura, Peru. Volume 96, Pages 917https://doi.org/10.1016/j.envsci.2019.02.005. 2019.

Peña-Arancibia, J.L., Bruijnzeel, L.A., Mulligan, M. and van Dijk, A.I.. Forests as 'sponges' and 'pumps': Assessing the impact of deforestation on dry-season flows across the tropics. Journal of Hydrology, 574, pp.946-963. 2019

Nimmo, J.R. Porosity and pore size distribution. In: Hillel, D. (Ed.), Encyclopedia of Soils in the Environment. Elsevier, London, pp. 295-303. 2004.

325 Rodenburg, J., Stein, A., van Noordwijk, M. and Ketterings, Q.M. Spatial variability of soil pH and phosphorus in relation to soil run-off following slash-and-burn land clearing in Sumatra, Indonesia. Soil and Tillage Research, 71(1), pp.1-14. 2003.

Sajikumar N. and Remya R.S. Impact of land cover and land use change on runoff characteristics. Journal of Environmental Management 161: 460-468. http://dx.doi.org/10.1016/j.jenvman.2014.12.041. 2015.

330 Shannon P.D., Swanston C.W., Janowiak M.K., Handler S.D., Schmitt K.M., Brandt L.A., Butler-Leopold P.R., Ontl T. Adaptation strategies and approaches for forested watersheds. Review article. Climate Services 13: 51-64. https://doi.org/10.1016/j.cliser.2019.01.005. 2019. 
Tanika L, Khasanah N, Leimona B. Simulasi dampak perubahan tutupan lahan terhadap neraca air di DAS dan Sub-DAS Rejoso menggunakan model GenRiver. Report. Bogor, Indonesia: World Agroforestry Centre (ICRAF) Southeast Asia Regional Program. 2018

Teklay A., Dile Y.T., Setegn S.G., Solomon S. Demissie, S.S., Asfaw D.H. Evaluation of static and dynamic land use data for watershed hydrologic process simulation: A case study in Gummara watershed, Ethiopia. Catena 172: 65-75. https://doi.org/10.1016/j.catena.2018.08.013. 2019.

UN-Water. Sustainable Development Goal 6 Synthesis Report on Water and Sanitation. http://www.unwater.org/publications/highlights-sdg-6-synthesis-report-2018-on-water-and-sanitation-2/. 2018.

U.S. Geological Survey (USGS). Landsat 8 OLI (2019-10-18 (6,53). https://earthexplorer.usgs.gov/ 2019.

Walkley, A., Black, I.A. An examination of the Degtjareff method for determining soil organic matter, and a proposed modification of the chromic acid titration method. Soil Science 37, 29-38. 1934.

van Noordwijk, M., Heinen, M. and Hairiah, K. Old tree root channels in acid soils in the humid tropics: important for crop root penetration, water infiltration and nitrogen management. Plant Soil 134, 7-44. 1991.

van Noordwijk, M., Bayala, J., Hairiah, K., Lusiana, B., Muthuri, C., Khasanah, N., \& Mulia, R. Agroforestry solutions for buffering climate variability and adapting to change. In: Fuhrer, J., \& Gregory, P. J. (Eds.) Climate change Impact and Adaptation in Agricultural Systems. Wallingford, UK: CAB-International, 216-232. 2014.

van Noordwijk M., Tanika L., Betha Lusiana B. Flood risk reduction and flow buffering as ecosystem services -Part 2: Land use and rainfall intensity effects in Southeast Asia. Hydrol. Earth Syst. Sci., 21, 2341-2360, http://doi:10.5194/hess-212341-2017. 2017.

van Noordwijk M, Bargues-Tobella A, Muthuri CW, Gebrekirstos A, Maimbo M, Leimona B, Bayala J, Ma X, Lasco R, Xu J, Ong CK. Agroforestry as part of nature-based water management. pp 261-287 In: van Noordwijk M (Ed.) Sustainable Development Through Trees on Farms: Agroforestry in its Fifth Decade. World Agroforestry (ICRAF), Bogor, Indonesia. 2019

Wiersum, K.F. Surface erosion under various agroforestry systems. In: Proc. Symp. Effects of forest land use on erosion and slope stability. Environment \& Policy Institute East-West Center, Honolulu, pp. 231-239. 1984

Yalew S.G., Pilz T., Schweitzer C., Liersch S., van der Kwast J., van Griensven A., Mul M.L., Dickens C., van der Zaag P. oupling land-use change and hydrologic models for quantification of catchment ecosystem services. Environmental Modelling and Software 109: 315-328. https://doi.org/10.1016/j.envsoft.2018.08.029. 2018. 2018. 
https://doi.org/10.5194/hess-2020-2

Preprint. Discussion started: 20 February 2020

(c) Author(s) 2020. CC BY 4.0 License.

(c) (i)
Hydrology and Earth System Sciences

Discussions

Zhang, J., van Meerveld, H.I., Tripoli, R. and Bruijnzeel, L.A. Runoff response and sediment yield of a landslide-affected fireclimax grassland micro-catchment (Leyte, the Philippines) before and after passage of typhoon Haiyan. Journal of hydrology, 565, 524-537. 2018.

Zhang, J., Bruijnzeel, L.A., Quiñones, C.M., Tripoli, R., Asio, V.B. and van Meerveld, H.J. Soil physical characteristics of a degraded tropical grassland and a 'reforest': Implications for runoff generation. Geoderma, 333, 163-177. 2019.

Zhao Y., Wang Y., Wang L., Zhang X., Yu Y., Zhao J., Lin H., Chen Y., Zhou W., An Z. Exploring the role of land restoration in the spatial patterns of deep soil water at watershed scales. Catena 172: 387-396. https://doi.org/10.1016/j.catena.2018.09.004. 2019.

Zhipeng L., Donghao M., Wei H., Xuelin L. Land use dependent variation of soil water infiltration characteristics and their scale-specific controls. Soil \& Tillage Research 178: 139-149. https://doi.org/10.1016/j.still.2018.01.001. 2018.

Zwartendijk, B.W., Van Meerveld, H.J., Ghimire, C.P., Bruijnzeel, L.A., Ravelona, M. and Jones, J.P.G. Rebuilding soil hydrological functioning after swidden agriculture in eastern Madagascar. Agriculture, ecosystems \& environment, 239, pp.101-111. 2017. 
https://doi.org/10.5194/hess-2020-2

Preprint. Discussion started: 20 February 2020

(c) Author(s) 2020. CC BY 4.0 License.

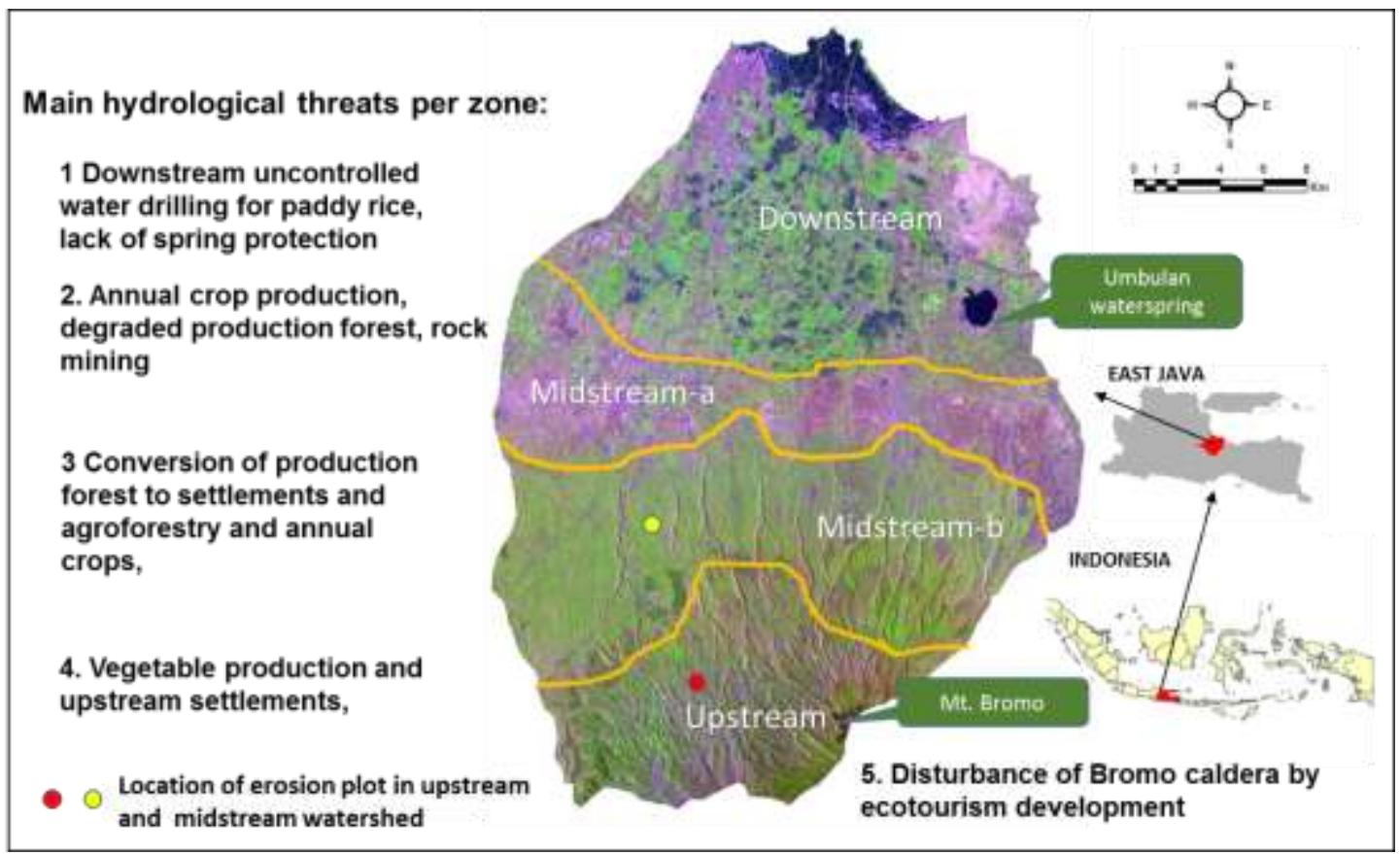

Figure 1. The Rejoso Watershed from upstream (at the bottom) to sea level and land uses considered to be a hydrological threat; purple indicates open soil, green tree cover. (Modified from USGS, 2019).

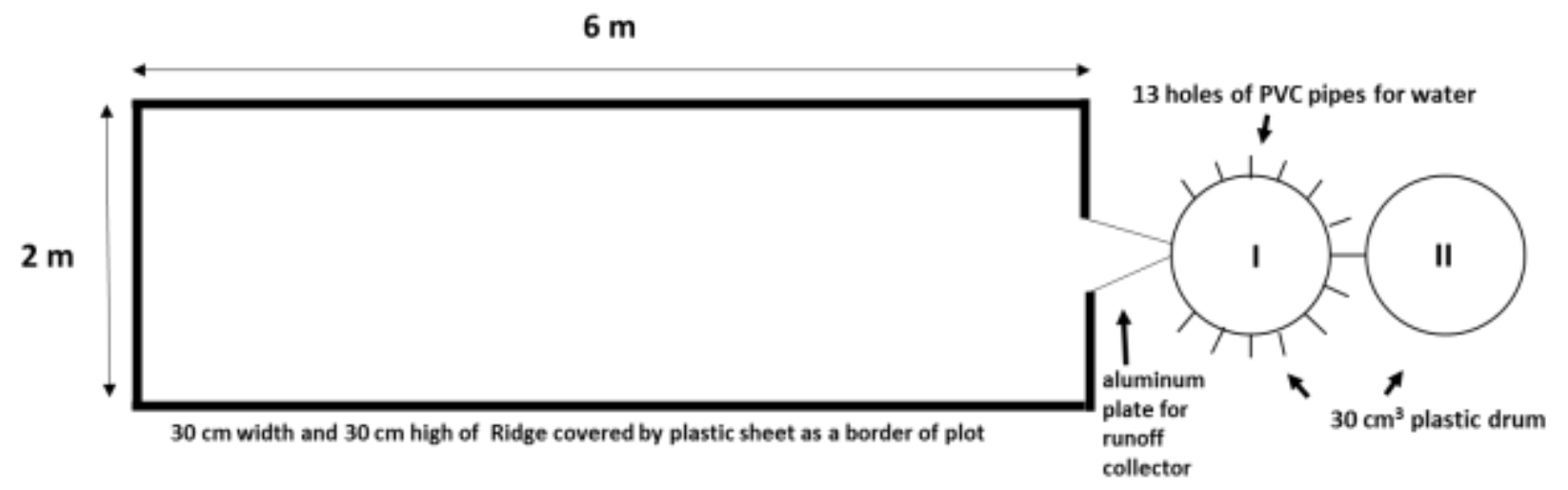

Figure 2. Runoff and soil erosion plot design. 

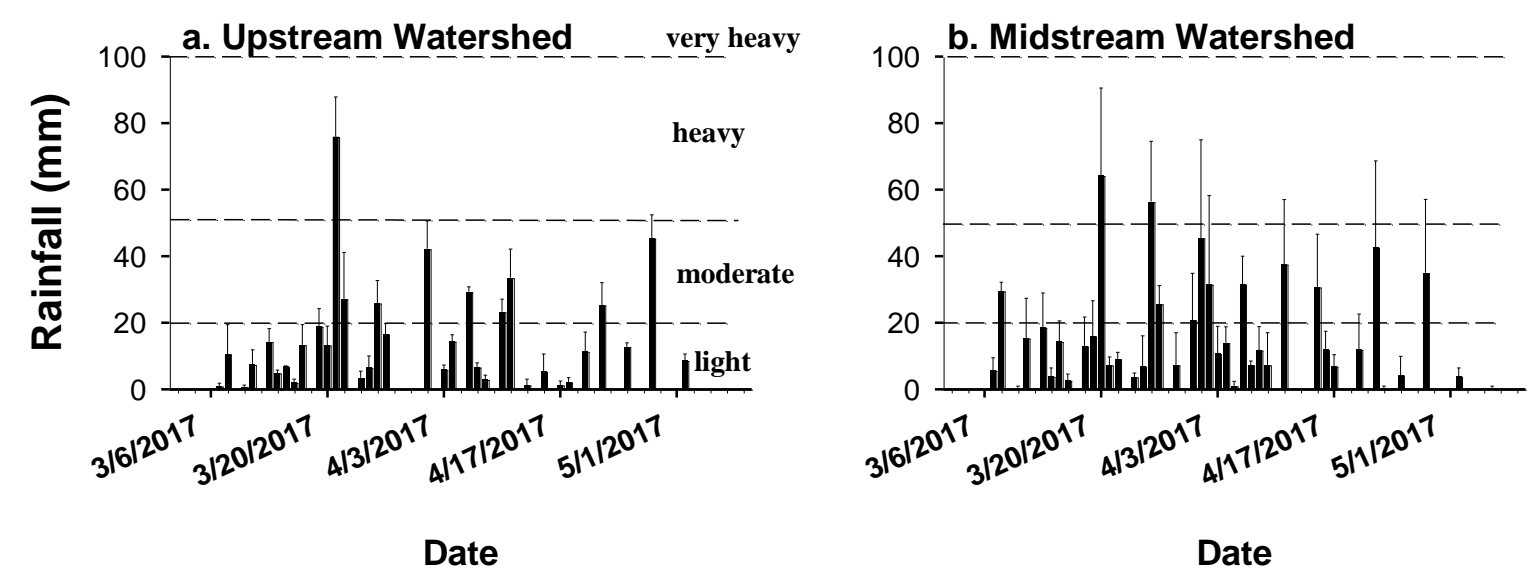

Figure 3. Distribution of rainfall during observation between March to May 2017 in the Rejoso watershed.
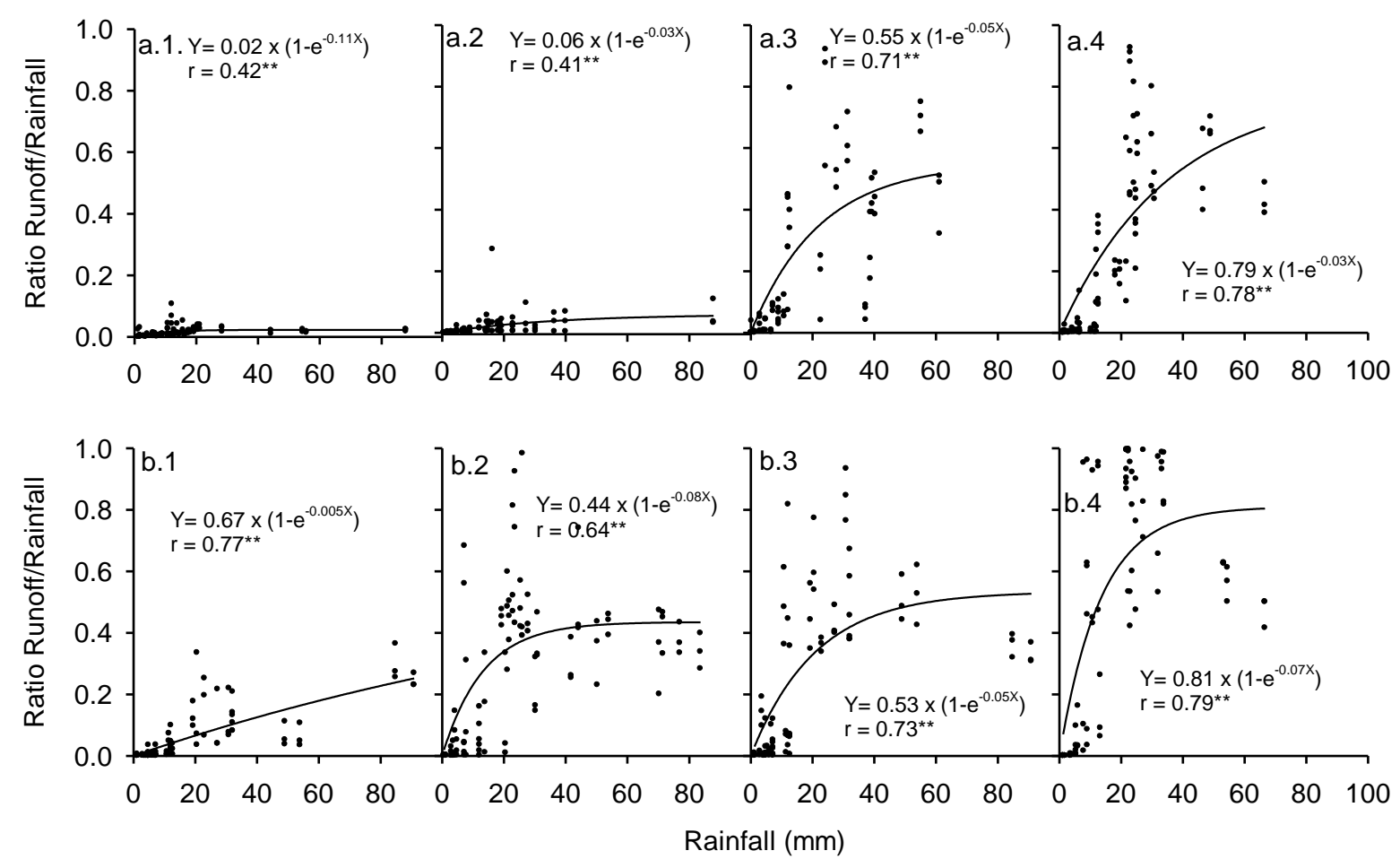

Figure 4. The relationship between surface runoff / rainfall ratio and the amount of rainfall in production forest and agroforestry systems in the Rejoso watershed (a: Upstream Rejoso Watershed; b: Midstream Rejoso Watershed). 
https://doi.org/10.5194/hess-2020-2

Preprint. Discussion started: 20 February 2020

(c) Author(s) 2020. CC BY 4.0 License.
Hydrology and
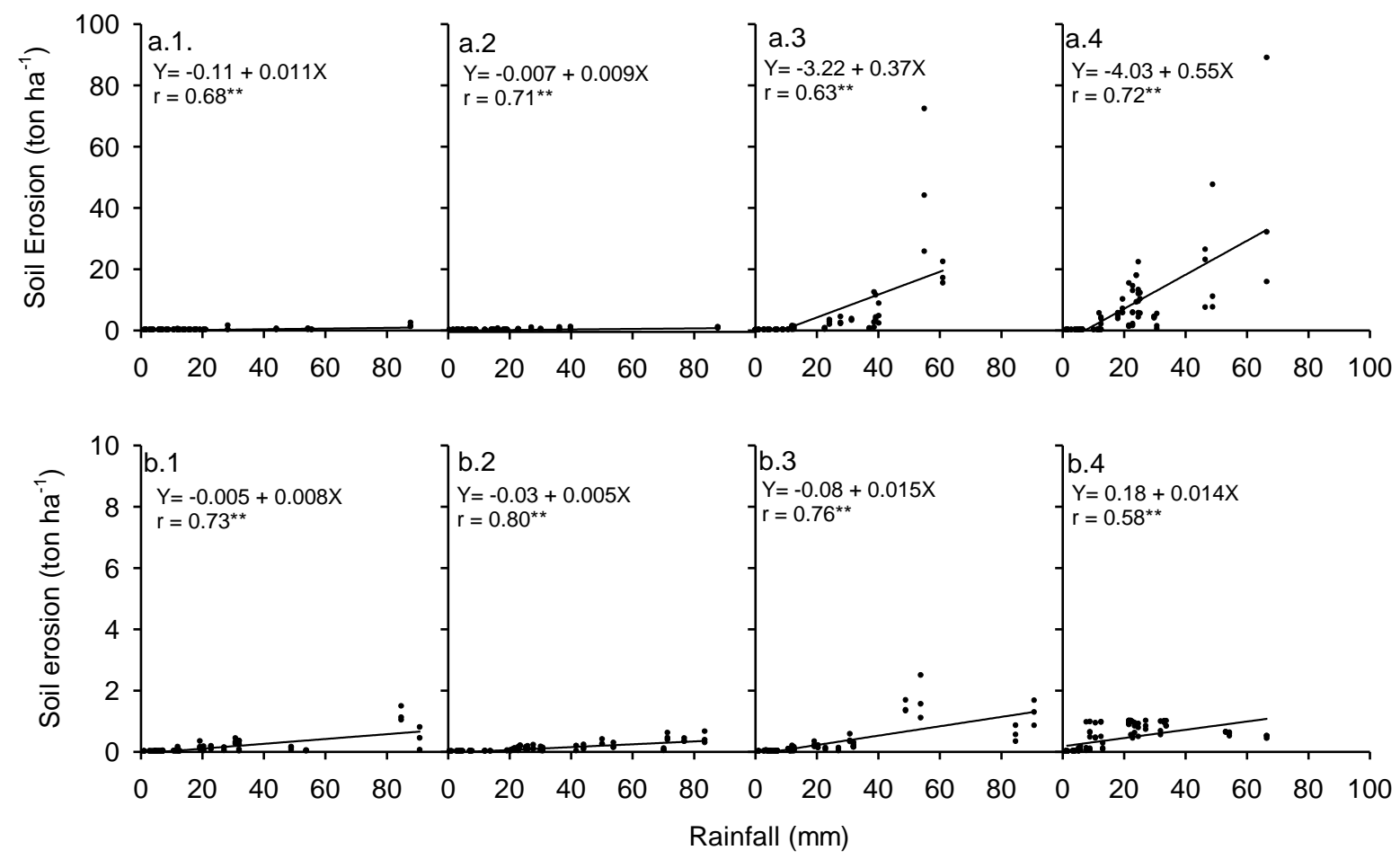

Figure 5: Soil erosion in relation to daily rainfall rates in production forest and agroforestry (a: Upstream Rejoso Watershed; b: Midstream Rejoso Watershed) 
https://doi.org/10.5194/hess-2020-2

Preprint. Discussion started: 20 February 2020

(c) Author(s) 2020. CC BY 4.0 License.

(c) (i)
Hydrology and

a. Upstream Rejoso watershed

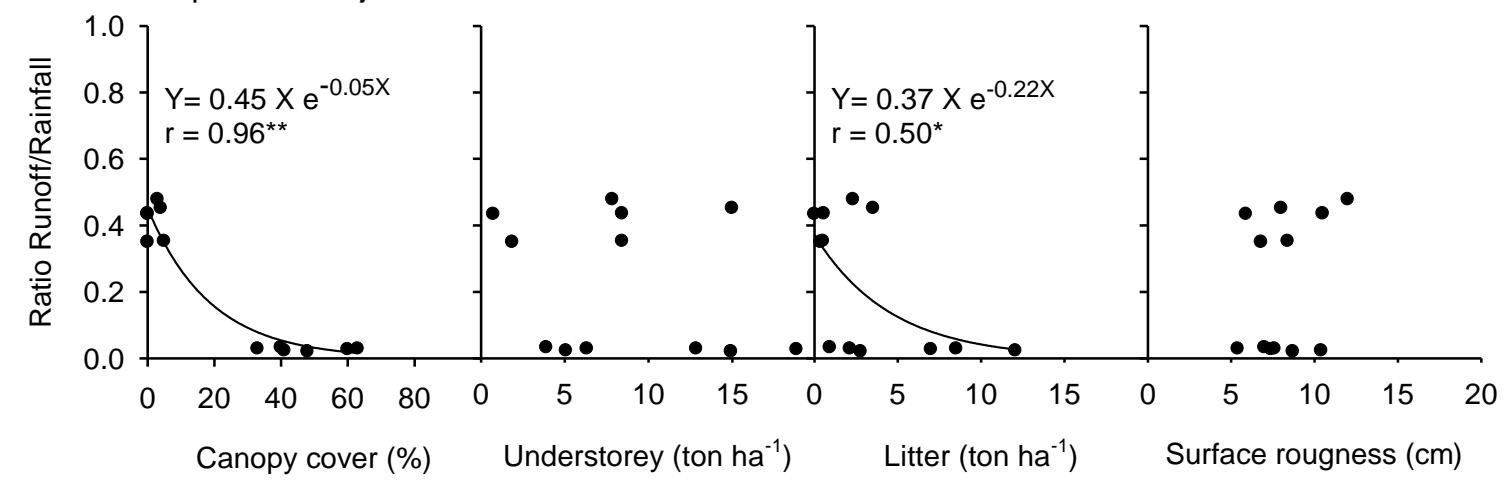

b. Midstream Rejoso watershed

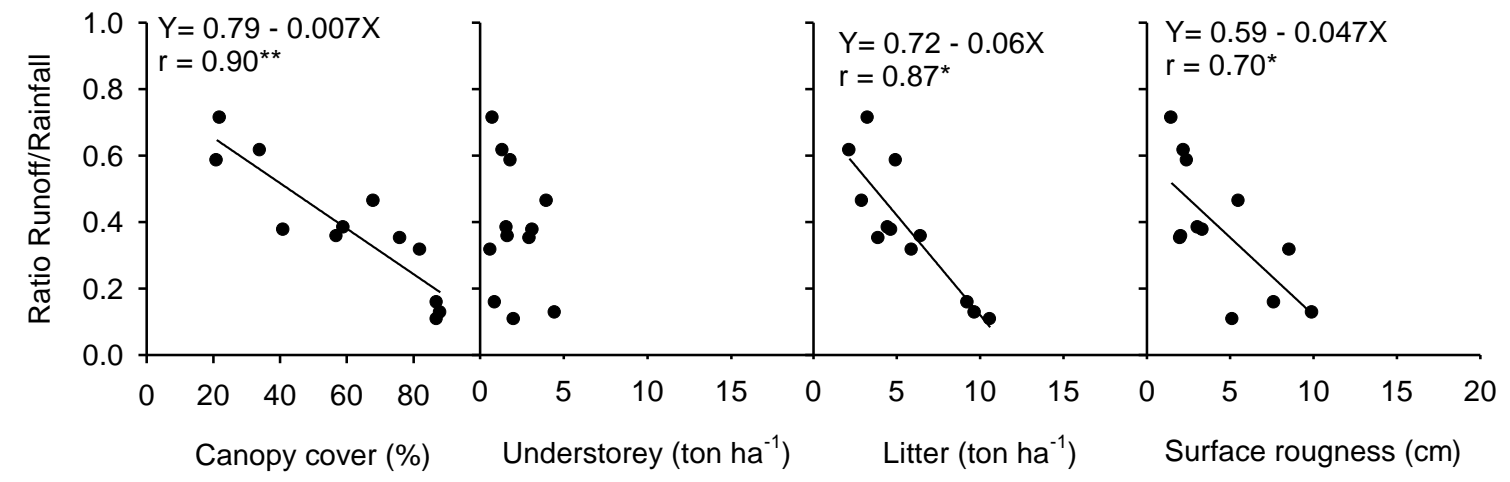

Figure 6. The runoff / rainfall ratio as function of tree canopy cover, understorey vegetation, litter necromass, and land surface roughness. 
https://doi.org/10.5194/hess-2020-2

Preprint. Discussion started: 20 February 2020

(c) Author(s) 2020. CC BY 4.0 License.
Hydrology and

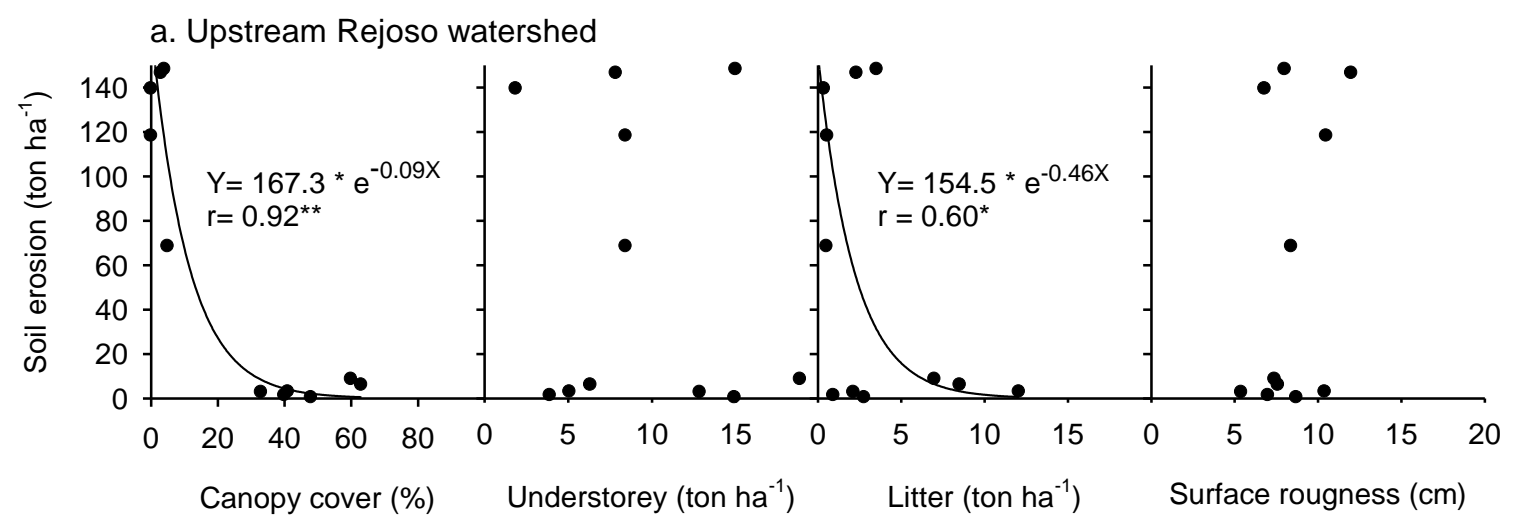

b. Midstream Rejoso watershed

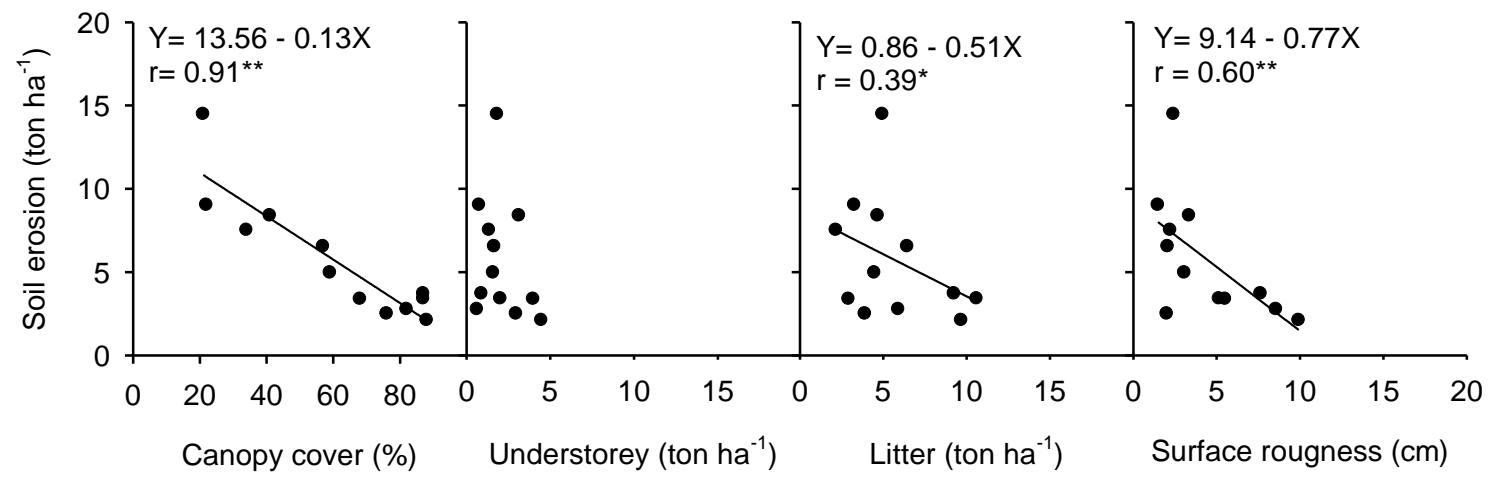

Figure 7. Soil erosion in relation to tree canopy cover, understorey vegetation, litter necromass, and land surface roughness. 
Table 1. Land use, vegetation, soil conservation measure and slope of measurement plots

\begin{tabular}{|c|c|c|c|c|}
\hline Code & Land use & Vegetation & Terracing & $\begin{array}{l}\text { Slope at plot } \\
\text { level }(\%)\end{array}$ \\
\hline \multicolumn{5}{|c|}{ Upstream Rejoso watershed } \\
\hline UT1 & Old production forest & Pine (Pinus merkusii) + grass & None & $35-40$ \\
\hline UT2 & $\begin{array}{l}\text { Young production } \\
\text { forest }\end{array}$ & Pine + grass & None & $50-60$ \\
\hline UT3 & Agroforestry & $\begin{array}{l}\text { Strip cemara (Casuarina junghuniana) }+ \\
\text { Cabbage }\end{array}$ & None & $40-50$ \\
\hline UT4 & Arable land & Banana, maize, carrot & None & $40-50$ \\
\hline \multicolumn{5}{|c|}{ Midstream Rejoso watershed } \\
\hline MT1 & Old production forest & $\begin{array}{l}\text { Mix Pine or mahoni (Swietenia macrophylla), } \\
\text { banana, salak (Salacca zalacca), taro (Colocasia } \\
\text { esculenta), elephant grass (Miscanthus } \\
\text { giganteus). }\end{array}$ & $\begin{array}{l}\text { Bench } \\
\text { terrace }\end{array}$ & $3-8$ \\
\hline MT2 & Agroforestry & $\begin{array}{l}\text { Coffee-based mix with durian (Durio } \\
\text { zibethinus), mahoni, Leucaena leucocaphala, } \\
\text { Paraserianthes falcataria, Albizia saman, dadap } \\
\text { (Erythrina variegata), banana }\end{array}$ & $\begin{array}{l}\text { Bench } \\
\text { terrace }\end{array}$ & $3-8$ \\
\hline MT3 & Agroforestry & Clove (Syzygium aromaticum), banana & $\begin{array}{l}\text { Bench } \\
\text { terrace }\end{array}$ & $3-8$ \\
\hline MT4 & Agroforestry & $\begin{array}{l}\text { Manggo (Mangifera indica), durian, dapap, } \\
\text { maize, cassava, groundnut }\end{array}$ & $\begin{array}{l}\text { Bench } \\
\text { terrace }\end{array}$ & $3-8$ \\
\hline
\end{tabular}


https://doi.org/10.5194/hess-2020-2

Preprint. Discussion started: 20 February 2020

(c) Author(s) 2020. CC BY 4.0 License.

(c) (i)
Hydrology and

Earth System

Sciences

Discussions

Table 2. Soil texture, bulk density, soil porosity and organic C of runoff plots

\begin{tabular}{|c|c|c|c|c|c|c|c|}
\hline \multirow{2}{*}{$\begin{array}{l}\text { Location } \\
\text { Code }\end{array}$} & \multicolumn{3}{|c|}{ Soil texture $(\%)^{*}$} & \multirow{2}{*}{$\begin{array}{l}\text { Bulk Density } \\
\qquad\left(\mathrm{g} \mathrm{cm}^{-3}\right)^{*}\end{array}$} & \multirow{2}{*}{$\begin{array}{l}\text { Particle Density } \\
\qquad\left(\mathrm{g} \mathrm{cm}^{-3}\right)^{*}\end{array}$} & \multirow{2}{*}{$\begin{array}{l}\text { Soil porosity } \\
(\%)^{*}\end{array}$} & \multirow[t]{2}{*}{$\mathrm{C}_{\text {org }}(\%)^{*}$} \\
\hline & Sand & Silt & Clay & & & & \\
\hline \multicolumn{8}{|c|}{ Upstream Rejoso watershed: Andisols } \\
\hline UT1 & $18 \mathrm{a}$ & $52 \mathrm{ab}$ & $31 \mathrm{a}$ & $0.78 \mathrm{a}$ & $2.20 \mathrm{a}$ & $65 \mathrm{a}$ & $2.45 \mathrm{~b}$ \\
\hline UT2 & $17 \mathrm{a}$ & $49 \mathrm{a}$ & $34 \mathrm{a}$ & $0.79 \mathrm{a}$ & $2.36 \mathrm{~b}$ & $67 \mathrm{a}$ & $1.70 \mathrm{a}$ \\
\hline UT3 & $12 \mathrm{a}$ & $55 \mathrm{~b}$ & $33 \mathrm{a}$ & $0.81 \mathrm{ab}$ & $2.20 \mathrm{a}$ & $63 \mathrm{a}$ & $2.00 \mathrm{ab}$ \\
\hline UT4 & $14 \mathrm{a}$ & $54 \mathrm{ab}$ & 33 a & $0.95 \mathrm{~b}$ & $2.43 \mathrm{~b}$ & $61 \mathrm{a}$ & $1.47 \mathrm{~b}$ \\
\hline LSD & & 4.86 & & 0.14 & 0.14 & 6.9 & 0.66 \\
\hline \multicolumn{8}{|c|}{ Midstream Rejoso watershed: Inceptisols } \\
\hline MT1 & $11 \mathrm{a}$ & $48 \mathrm{~b}$ & $41 \mathrm{a}$ & $0.88 \mathrm{a}$ & $2.26 \mathrm{a}$ & $61 \mathrm{a}$ & $1.58 \mathrm{~b}$ \\
\hline MT2 & $10 \mathrm{a}$ & $43 \mathrm{ab}$ & $47 \mathrm{ab}$ & $0.93 \mathrm{ab}$ & $2.34 \mathrm{a}$ & $62 \mathrm{a}$ & $2.02 \mathrm{~b}$ \\
\hline MT3 & $7 \mathrm{a}$ & $46 \mathrm{~b}$ & $47 \mathrm{ab}$ & $1.08 \mathrm{~b}$ & $2.42 \mathrm{a}$ & $56 \mathrm{~b}$ & $1.28 \mathrm{ab}$ \\
\hline MT4 & $11 \mathrm{a}$ & $35 \mathrm{a}$ & $54 \mathrm{~b}$ & $1.07 \mathrm{~b}$ & $2.35 \mathrm{a}$ & $55 \mathrm{~b}$ & $0.65 \mathrm{a}$ \\
\hline LSD & & 9.0 & 11.7 & 0.15 & & 3.44 & 0.78 \\
\hline
\end{tabular}

*The same letter indicates no statistically significant differences between location with Fisher's LSD test ( $<<0.05$ ).

415 
https://doi.org/10.5194/hess-2020-2

Preprint. Discussion started: 20 February 2020

(c) Author(s) 2020. CC BY 4.0 License.

(c) (i)
Hydrology and

Earth System

Sciences

Discussions

Table 3. Canopy cover, understory vegetation, litter necromass, and soil roughness of the sample plots

\begin{tabular}{|c|c|c|c|c|c|}
\hline Code & Land cover & $\begin{array}{c}\text { Tree canopy cover } \\
(\%)^{*}\end{array}$ & $\begin{array}{c}\text { Understorey } \\
\text { vegetation }\left(\mathrm{t} \mathrm{ha}^{-1}\right)^{*}\end{array}$ & Litter $\left(\mathrm{t} \mathrm{ha}^{-1}\right)^{*}$ & $\begin{array}{l}\text { Soil roughness } \\
(\%)^{*}\end{array}$ \\
\hline \multicolumn{6}{|c|}{ Upstream Rejoso watershed } \\
\hline UT1 & $\begin{array}{l}\text { Old production } \\
\text { forest }\end{array}$ & $55 \mathrm{~b}$ & $10.1 \mathrm{~b}$ & $9.2 \mathrm{~b}$ & $8.5 \mathrm{a}$ \\
\hline UT2 & $\begin{array}{l}\text { Young pro- } \\
\text { duction forest }\end{array}$ & $40 \mathrm{~b}$ & $10.5 \mathrm{~b}$ & $2.0 \mathrm{a}$ & $7.0 \mathrm{a}$ \\
\hline UT3 & Agroforestry & $4 \mathrm{a}$ & $10.1 \mathrm{~b}$ & $2.1 \mathrm{a}$ & $9.5 \mathrm{a}$ \\
\hline UT4 & Arable land & $0 \mathrm{a}$ & $3.7 \mathrm{a}$ & $0.3 \mathrm{a}$ & $7.7 \mathrm{a}$ \\
\hline LSD & & 15 & 5.6 & 3.7 & 4.6 \\
\hline \multicolumn{6}{|c|}{ Midstream Rejoso watershed } \\
\hline MT1 & $\begin{array}{l}\text { Old production } \\
\text { forest }\end{array}$ & $87 \mathrm{c}$ & $2.5 \mathrm{a}$ & $9.8 \mathrm{~b}$ & $7.6 \mathrm{~b}$ \\
\hline MT2 & Agroforestry & $75 \mathrm{c}$ & $2.5 \mathrm{a}$ & $4.8 \mathrm{a}$ & $5.4 \mathrm{ab}$ \\
\hline MT3 & Agroforestry & $52 \mathrm{~b}$ & $2.1 \mathrm{a}$ & $5.2 \mathrm{a}$ & $2.8 \mathrm{a}$ \\
\hline MT4 & Agroforestry & $26 \mathrm{a}$ & $1.3 \mathrm{a}$ & $3.5 \mathrm{a}$ & $2.0 \mathrm{a}$ \\
\hline LSD & & 14 & 2.6 & 2.4 & 4.5 \\
\hline
\end{tabular}

*The same letter indicates no statistically significant differences between location with Fisher's LSD test ( $p<0.05)$. 
https://doi.org/10.5194/hess-2020-2

Preprint. Discussion started: 20 February 2020

(c) Author(s) 2020. CC BY 4.0 License.

(c) (i)
Hydrology and

Earth System

Sciences

Discussions

Table 4. Rainfall, runoff, ratio runoff/rainfall and soil erosion in the runoff plots in each land cover type

\begin{tabular}{|c|c|c|c|c|c|}
\hline Code & Land cover & $\begin{array}{l}\text { Ranfall } \\
(\mathrm{mm})\end{array}$ & Runoff $(\mathrm{mm}) *$ & $\begin{array}{c}\text { Runoff/ rainfall } \\
\text { ratio* }\end{array}$ & Soil erosion $\left(\text { ton } \mathrm{ha}^{-1}\right)^{*}$ \\
\hline \multicolumn{6}{|c|}{ Upstream Rejoso watershed } \\
\hline UT1 & $\begin{array}{l}\text { Old production } \\
\text { forest }\end{array}$ & 555 & $14.3 \mathrm{a}$ & $0.03 \mathrm{a}$ & $5.86 \mathrm{a}$ \\
\hline UT2 & $\begin{array}{l}\text { Young pro- } \\
\text { duction forest }\end{array}$ & 492 & $13.2 \mathrm{a}$ & $0.03 \mathrm{a}$ & $1.47 \mathrm{a}$ \\
\hline UT3 & Agroforestry & 476 & $203.3 \mathrm{~b}$ & $0.43 \mathrm{~b}$ & $120.98 \mathrm{~b}$ \\
\hline UT4 & Arable land & 556 & $225.7 \mathrm{~b}$ & $0.41 \mathrm{~b}$ & $163.22 \mathrm{~b}$ \\
\hline LSD & & & 46.3 & 0.09 & 87 \\
\hline \multicolumn{6}{|c|}{ Midstream Rejoso watershed } \\
\hline MT1 & $\begin{array}{l}\text { Old production } \\
\text { forest }\end{array}$ & 616 & $80.2 \mathrm{a}$ & $0.13 \mathrm{a}$ & $3.07 \mathrm{a}$ \\
\hline MT2 & Agroforestry & 841 & $316.3 \mathrm{c}$ & $0.38 \mathrm{~b}$ & $2.88 \mathrm{a}$ \\
\hline MT3 & Agroforestry & 616 & $228.8 \mathrm{~b}$ & $0.37 \mathrm{~b}$ & $6.63 \mathrm{ab}$ \\
\hline MT4 & Agroforestry & 541 & $344.9 \mathrm{c}$ & $0.64 \mathrm{c}$ & $10.33 \mathrm{~b}$ \\
\hline LSD & & & 86.6 & 0.12 & 4.22 \\
\hline
\end{tabular}

440 *The same letter indicates no statistically significant differences between location with Fisher's LSD test ( $p<0.05)$. 